The Truth Behind The Decision of Consumers in Buying Counterfeit Cosmetics Product: A Qualitative Phenomenological Research by Risca Kurnia Sari, Achmad Soediro, Fatchur Rochman

\title{
The Truth Behind The Decision of Consumers in Buying Counterfeit Cosmetics Product: A Qualitative Phenomenological Research
}

\author{
Risca Kurnia Sari *) \\ Achmad Soediro **) \\ Fatchur Rochman ***)
}

\begin{abstract}
Research conducted is a type of qualitative phenomenological research that reveal and understand the meaning behind the phenomenon of the actions of individuals who perform various actions on the basis of their own perceptions as well as aspects of the background of the action. The number of informants in this study are six people. Sampling method of this study used purposive sampling with snowball sampling method. The findings shows that well recognized or reputable brand considered to be one of the reasons consumers choose to buy stimulation of brand POND'S. Marketing stimuli such as advertising on television, the product that suits consumer needs in affordable price can stimulate consumers buying decision. Low price of POND'S counterfeit product is the main considerations in encouraging buying decision. High consumer loyalty toward original POND'S brand made them decide to buy counterfeit POND'S without considering the authenticity and its side effect on consumer health. Reference groups that dominate consumer minds in buying the counterfeit POND'S product are workmate and store employees where the product is sold. Motivation in seeking new products and the high level of trust toward Unilever brand (POND'S) encourages consumers to buy counterfeit POND'S. Private sources (office colleagues) and commercial (TV advertisement) considered as main information sources for a consumer in buying POND'S and counterfeit POND'S counterfeit.
\end{abstract}

Keywords: Consumer Behavior; Cosmetics; Counterfeit Product

\section{INTRODUCTION}

\subsection{Research Background}

The cosmetics industry in Indonesia is currently undergoing rapid growth. Cosmetics have been an essential part of a woman's daily routine. The data from The International Cosmetics Club shows that Indonesia's imports of cosmetic products reach Rp. 4 billion up to Rp. 10 billion each month. In fact, in 2006, cosmetics imports reached Rp 1 trillion throughout the year. Meanwhile, in the local market, according to the Indonesian Cosmetics Association (Petosmi), the cosmetic sales turnover of a big cosmetics company can reach up to Rp. 40 billion in one month. This shows that cosmetics use in Indonesia is very popular. Over time, cosmetics become a primary need for most women. This provides the cosmetics industry in Indonesia an opportunity to bring a lot of new products, which then results in fairly tight market competition. This competition is not only among original and legal cosmetics products - counterfeit and unlicensed beauty products also start to flood the market. Huge profit is the main reason why some manufacturers produce counterfeit cosmetics. Hidayat \& Mizerski (2005) present several supporting reasons for why counterfeit make-up products are made, which is shown in Table 1. 
Table 1 Reasons for Counterfeit Product

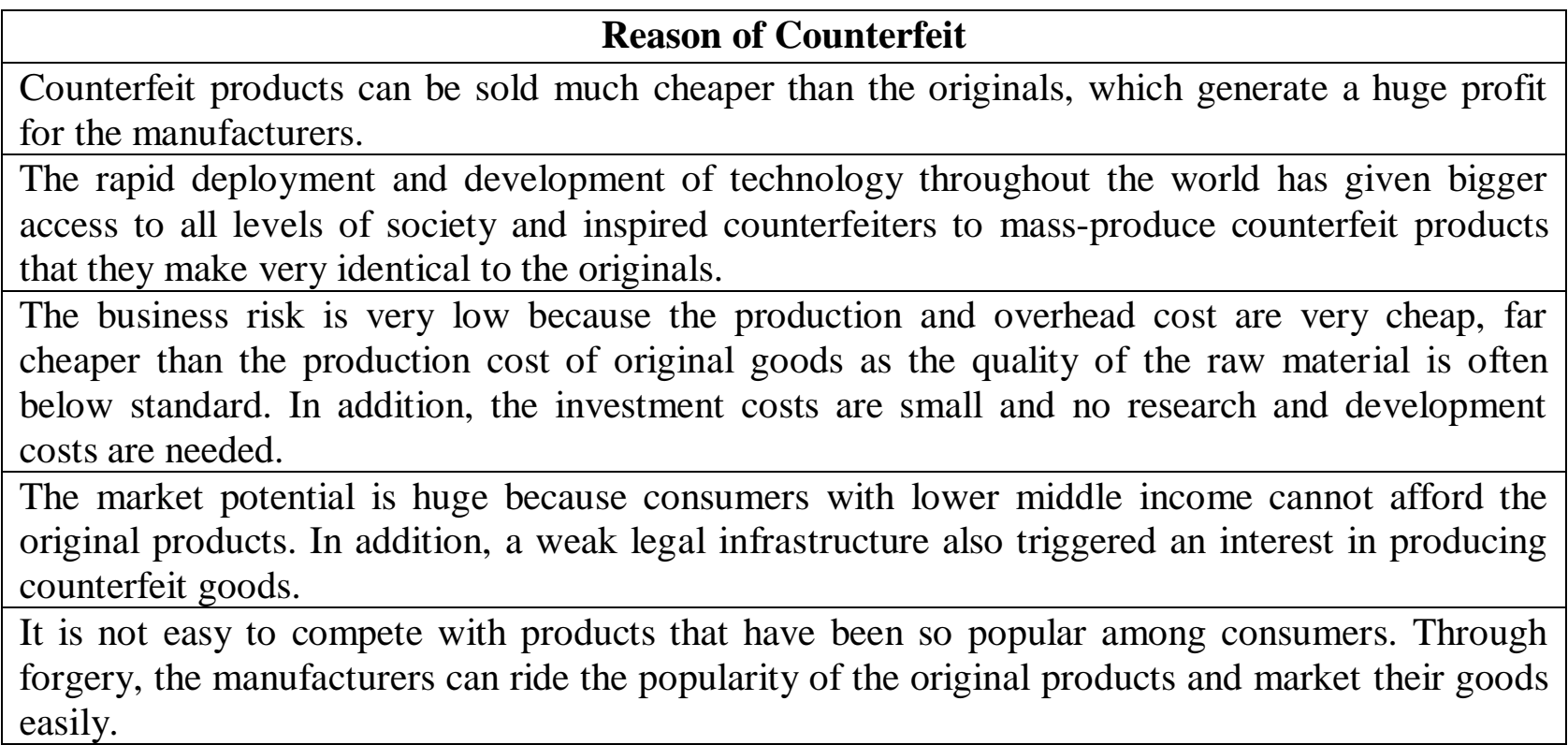

Source: Hidayat \& Mizerski (2005)

This research focuses on the purchase and use of counterfeit products of POND'S brand that are widely circulated especially in the city of Malang, East Java. The researcher's interest in consumer behavior in purchasing counterfeit products of POND'S brand in the city was driven by the existing phenomenon.

\subsection{Research Problem}

a) How do consumers buy and use counterfeit POND'S products?

b) Why do consumers buy and use counterfeit POND'S products?

c) What is the consumers' behavior in responding to counterfeit POND'S products?

\subsection{Research Purpose}

The purpose of a study is to discover, develop, and prove knowledge, therefore, the purposes of this study can be described as below;

a) To find out how the consumers buy and use counterfeit POND'S products.

b) To explore the underlying causes of why consumers buy and use counterfeit POND'S products.

c) To find out consumers' behavior in responding to POND'S counterfeit products.

\section{THEORETICAL FRAMEWORK}

\subsection{Counterfeiting}

Counterfeiting is an act of making a product by copying or imitating the physical appearance of an original product to mislead consumers that it is the product of another party. Products that violate trademarks, copyright infringement, and packaging, label, and brand regulations are part of counterfeiting (Tommy, 2012). Tommy (2012) also disclosed several consumer classifications related to such products, namely:

a) Deceptive counterfeiting, for example, when fraud is done unbeknownst to the consumer with the aim to deceive and even lie to them by stating that the goods are genuine. 
b) Non-deceptive counterfeiting, for example, when the products being sold are acknowledged as counterfeit, and the information is given to consumers who have the intention to make a purchase.

The phenomenon of counterfeit products of POND'S cosmetic brand is more appropriately classified into non-deceptive counterfeiting as counterfeit products are completely different from the product variants that are officially produced by PT Unilever Indonesia Tbk. Consumers supposedly know that the products are not original or officially manufactured by the company.

A previous qualitative study conducted by Purnamawati (2009) under the title Female Road Sweepers Behavior Toward Whitening Cosmetics in Medan City in 2009 found that most of the female road sweepers in Medan thought beauty is strongly defined by light or fair skin tone. The physical and social environments, sources of information and references, and possible situations lead the female workers' behavior toward using skin whitening products. However, some of the women no longer use the whitening cosmetics for fear of having side effects, which allows for awareness campaign of cosmetic safety among women.

That study was not entirely identical with the topic that will be discussed in this research, because the 2009 study focused more on the design of behavioral change model against whitening cosmetics, where the researcher revealed changes in the behavior of Health Belief Model Rosenstock. The similarity with this research is that both examine the behavior of consumers who use whitening beauty products that contain ingredients that are harmful to the skin and overall health. The phenomenon of the increasing counterfeiting business is indeed related to consumer behavior in making decisions to fulfill their needs for goods and services (Kotler \& Armstrong, 2008).

\subsection{Consumer Behavior}

The American Marketing Association defines consumer behavior as a dynamic interaction of influences and awareness, behavior, and the environment in which humans exchange aspects of their lives. In other words, consumer behavior includes thoughts and feelings experienced by humans and actions taken during the consumption process (Peter \& Olson, 2005). Consumer behavior focuses on activities related to individual consumption. Consumer behavior is also related to the reasons and pressures that affect the choice, purchase, use, and disposal of goods and services to satisfy personal needs and wishes (Hanna \& Wozniak, 2001).

\subsection{Consumer Attitude}

Behavior is an expression of a person's feelings that reflect his or her likes or dislike of an object. Because one's behavior is the result of a psychological process, it can not be observed directly, but it must be inferred from what is said and done (Tommy, 2012). Empirical studies have addressed the economic, quality, legal, or ethical factors that shape and influence the behavior of consumers (Ang, Cheng, Lim, \& Tambyah, 2001; Tommy, 2012). Usually, the choice of price also reflects a consumer's behavior toward the demand of counterfeit goods. The reason for this demand shifts from time to time. Initially, the motive in buying pirated products is financial constraints, but then it shifts towards a more positive outlook on those products. This means that the purchase of counterfeit products is not monopolized by consumers with low financial status. Instead, it has shifted to a wider group of consumers, including those with strong financial capabilities. That is why campaigns for piracy eradication that urge consumers to stay away from counterfeit products are becoming increasingly less effective - there is now a positive outlook toward those counterfeit products. 
JEMA: Jurnal Ilmiah Bidang Akuntansi dan Manajemen, Vol. 15 No. 2 (2018)

http://riset.unisma.ac.id/index.php/jema (e-ISSN : 2597-4071)

\section{RESEARCH METHOD}

\subsection{Research Design}

A qualitative phenomenological research design is chosen to describe consumers' experiences, especially in Malang, when buying and using counterfeit POND'S products. Phenomenological research is classified as a study of micro-sociology which reveals the understanding of the meaning and/or reflection of meaning at the micro level and is one of the field studies with participatory observation strategies. Qualitative research is a rich type of research in terms of people, place, and conversation descriptions, which is not easily handled using statistical procedures (Bogdan \& Biklen, 2003). The purpose of the phenomenological research design is to describe what the informants experience regarding a phenomenon (Creswell, 2007), particularly the experiences related to the phenomenon of the counterfeits POND'S products purchase in Malang.

\subsection{Research Informants}

Data collected in this study used the Informants Eligibility Test Form (Screening Form), Demographic Questionnaire, First Interview Schedule and Second Interview Schedule. To elicit accuracy, the final summary of the first interview was presented to each of the informants during their second interview. Each informant was asked whether the summary of their experience was consistent with the purchase (use) of the counterfeit products of POND'S brand's and whether there were any other descriptions of their experience being omitted or lacking in summary. The sample determination in qualitative research is not based on statistical calculations. The selected sample serves to provide maximum information, not to be generalized (Sugiyono, 2011). Purposive sampling was used to select informants in this study. Using criterion sampling - one form of purposive sampling - certain informants were chosen to provide information that may not have been obtained from other informants (Maxwell, 2005). Criterion sampling requires that informants be selected based on the phenomena they experience during the study (Creswell, 2007). This study used the snowball sampling method, which was conducted in chains by requesting information from the people who have been contacted before (Poerwandari, 2001). At first, researchers asked some shop owners who sold counterfeit POND'S products about prospective subjects that could be used as informants in this study. Required informants were those who had experience as buyers and users of counterfeit POND'S cosmetic products and were able to reveal a comprehensive description of their experience (Burkholder, 2009).

Table 2 Research Informants

\begin{tabular}{|c|c|c|c|c|c|c|}
\hline No. & Informant & Age & Ethnicity & Last Education & Marital Status & Occupation \\
\hline 1. & Sulistina (INF1) & 45 & Javanese & Primary School & Married & Factory Worker \\
\hline 2. & Suhermin (INF2) & 34 & Javanese & Primary School & Married & Factory Worker \\
\hline 3. & Anisa (INF3) & 38 & Javanese & Primary School & Married & Housewive \\
\hline 4. & Nursiyah (INF4) & 45 & Javanese & Secondary School & Married & Factory Worker \\
\hline 5. & Tina (INF5) & 39 & Javanese & Primary School & Married & Office Girl \\
\hline 6. & Diah W (INF6) & 34 & Javanese & High School & Single Parent & Administrative Staff \\
\hline
\end{tabular}

Source: Primary Data Processed, 2018

The number of the informant in this research was 6 informants. The selected informants were those who filled out letters of willingness to participate and conduct interviews recorded 2 times. Informants who met the quantity and variation requirements were determined by saturations. Saturation is used when informants tend to provide redundant information instead of new information (Nieswiadomy, 2002).

JEMA: Jurnal Ilmiah Bidang Akuntansi dan Manajemen is licensed under a Creative Commons Attribution 4.0 International License 


\subsection{Research Framework}

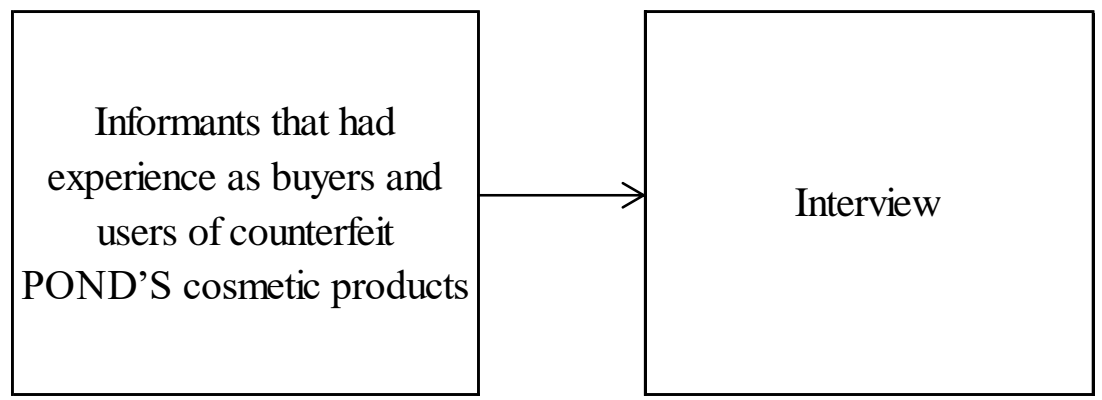

Picture 1 Research Framework

\section{RESEARCH RESULT AND ANALYSIS}

Table 3 Narrative Description of Counterfeit POND'S Products Information and Related Themes

\begin{tabular}{|c|c|c|c|}
\hline No. & Informant & Narrative Description & Related Theme \\
\hline 1. & Sulistina (INF1) & $\begin{array}{c}\text { Mrs. Sulistina first knew counterfeit POND'S } \\
\text { products from a friend at her workplace. That } \\
\text { friend was a seller of cosmetic products and } \\
\text { she offered Mrs. Sulistina to try the } \\
\text { (counterfeit) POND'S Make Up. }\end{array}$ & $\begin{array}{c}\text { Reference Group } \\
\text { (Social Factor) }\end{array}$ \\
\hline 2. & Suhermin (INF2) & $\begin{array}{c}\text { Bu Suhermin first got to know POND'S } \\
\text { products through the advertisement on } \\
\text { television. She also knew a friend who used } \\
\text { them and gave satisfactory reviews. }\end{array}$ & $\begin{array}{c}\text { Advertisement } \\
\text { (Marketing Stimuli) } \\
\text { Reference Group } \\
\text { (Social Factor) }\end{array}$ \\
\hline 3. & Anisa (INF3) & $\begin{array}{c}\text { Mrs. Anisa first found out about POND'S } \\
\text { powder from the owner of Asri Shop. }\end{array}$ & $\begin{array}{c}\text { Reference Group } \\
\text { (Social Factor) }\end{array}$ \\
\hline N. & Nursiyah (INF4) & $\begin{array}{c}\text { Nursiyah said she first saw POND'S products } \\
\text { at a shop that displayed a set of the brand's } \\
\text { powder, lipstick, eye shadow, and blush-on } \\
\text { which she thought had interesting colors. }\end{array}$ & $\begin{array}{c}\text { Reference Group } \\
\text { (Social Factor) } \\
\text { Product }\end{array}$ \\
(Marketing Stimuli) \\
\hline T.
\end{tabular}

Source: Primary Data Processed, 2018

JEMA: Jurnal Ilmiah Bidang Akuntansi dan Manajemen is licensed under a

Creative Commons Attribution 4.0 International License 
JEMA: Jurnal Ilmiah Bidang Akuntansi dan Manajemen, Vol. 15 No. 2 (2018)

http://riset.unisma.ac.id/index.php/jema (e-ISSN : 2597-4071)

Table 4 Narrative Description of the Reasons behind the Purchase and Use of Counterfeit POND'S Cosmetics

\begin{tabular}{|c|c|c|c|}
\hline No. & Informant & Narrative Description & Related Theme \\
\hline 1. & Sulistina (INF1) & $\begin{array}{l}\text { Mrs. Sulistina admitted she bought and tried } \\
\text { to use POND'S cosmetic products out of } \\
\text { curiosity. }\end{array}$ & $\begin{array}{l}\text { (Alternative } \\
\text { Evaluation) based on } \\
\text { encouragement or } \\
\text { intuition }\end{array}$ \\
\hline 2. & Suhermin (INF2) & $\begin{array}{l}\text { Mrs. Suhermin bought and used POND'S } \\
\text { products after seeing the advertisements on } \\
\text { TV and hearing about the testimony of a } \\
\text { friend who first used the brand. Mrs. } \\
\text { Suhermin also inquired further about POND'S } \\
\text { at the shop that sold its products. Because she } \\
\text { was interested and needed a moisturizer, she } \\
\text { decided to buy POND'S Age Miracle } \\
\text { (Unilever). }\end{array}$ & $\begin{array}{l}\text { Personal Sources } \\
\text { (Fellow Experience) } \\
\text { Commercial Sources } \\
\text { (Advertisement) } \\
\text { Reference Group } \\
\text { (Social Factors) }\end{array}$ \\
\hline 3. & Anisa (INF3) & $\begin{array}{l}\text { Mrs. Anisa was interested in buying and using } \\
\text { POND'S products mainly after seeing the } \\
\text { advertisement for the brand's moisturizer, Age } \\
\text { Miracle on TV. }\end{array}$ & $\begin{array}{c}\text { Advertisement } \\
\text { (Marketing Stimuli) }\end{array}$ \\
\hline 4. & Nursiyah (INF4) & $\begin{array}{l}\text { Mrs. Nursiyah admitted to buying and using } \\
\text { POND'S because he wanted to switch from } \\
\text { Viva and try new beauty products. }\end{array}$ & $\begin{array}{c}\text { (Alternative } \\
\text { Evaluation) } \\
\text { Based on } \\
\text { encouragement or } \\
\text { intuition }\end{array}$ \\
\hline 5. & Tina (INF5) & $\begin{array}{l}\text { Mrs. Tina said that the reason she bought and } \\
\text { used POND'S products. She thought that it } \\
\text { was the brand of cosmetics that would help } \\
\text { make her face clean and wrinkle-free pretty } \\
\text { quickly. Moreover, a friend of hers who was a } \\
\text { POND'S user testified that it was a good } \\
\text { product with an affordable price. }\end{array}$ & $\begin{array}{c}\text { Motivation } \\
\text { (Psychological Factor) } \\
\text { Reference Group } \\
\text { (Social Factor) } \\
\text { Price } \\
\text { (Marketing Stimuli) }\end{array}$ \\
\hline 6. & $\begin{array}{c}\text { Diah Widyastuti } \\
\text { (INF6) }\end{array}$ & $\begin{array}{l}\text { Diah was interested in buying and using } \\
\text { POND'S cosmetics after seeing the brand's } \\
\text { advertisement on television. }\end{array}$ & $\begin{array}{c}\text { Advertisement } \\
\text { (Marketing Stimuli) }\end{array}$ \\
\hline
\end{tabular}

Source: Primary Data Processed, 2018

JEMA: Jurnal Ilmiah Bidang Akuntansi dan Manajemen is licensed under a

Creative Commons Attribution 4.0 International License 
Table 5 Narrative Description of the Reasons behind the Purchase and Use of Counterfeit POND'S Cosmetics

\begin{tabular}{|c|c|c|c|}
\hline No. & Informant & Narrative Description & Related Theme \\
\hline 1. & Sulistina (INF1) & $\begin{array}{l}\text { Mrs. Sulistina bought and used counterfeit } \\
\text { POND'S upon the recommendation of one of } \\
\text { her friends who was selling the brand's beauty } \\
\text { products. }\end{array}$ & $\begin{array}{l}\text { Reference Group (Social } \\
\text { Factor) }\end{array}$ \\
\hline 2. & Suhermin (INF2) & $\begin{array}{l}\text { Mrs. Suhermin admitted that she used } \\
\text { counterfeit POND'S powder because she had } \\
\text { been using POND'S original moisturizer from } \\
\text { Unilever. She thought that both items did not } \\
\text { have that much difference and were issued by } \\
\text { PT Unilever Indonesia Tbk. }\end{array}$ & $\begin{array}{c}\text { Belief (Psychological } \\
\text { Factor) }\end{array}$ \\
\hline 3. & Anisa (INF3) & $\begin{array}{l}\text { Mrs. Anisa assumed that by using } \\
\text { (counterfeit) POND'S powder would help her } \\
\text { have better skin as proved by a friend of hers. } \\
\text { She also got the recommendation from the } \\
\text { store that sold the product. }\end{array}$ & $\begin{array}{l}\text { Reference Group (Social } \\
\text { Factor) }\end{array}$ \\
\hline 4. & Nursiyah (INF4) & $\begin{array}{l}\text { Mrs. Nursiyah purchased counterfeit POND'S } \\
\text { Makeup because she was interested in the } \\
\text { compact packaging that consisted of powder, } \\
\text { blush on, eye shadow, mascara, and lipstick. } \\
\text { She thought this package was convenient to } \\
\text { carry around. } \\
\text { People's recommendations had a small part in } \\
\text { her decision to use the products because she } \\
\text { relied more on her intuition when buying } \\
\text { beauty products. }\end{array}$ & $\begin{array}{c}\text { Product } \\
\text { (Marketing Stimuli) } \\
\begin{array}{c}\text { (Alternative Evaluation) } \\
\text { based on encouragement } \\
\text { or intuition }\end{array} \\
\end{array}$ \\
\hline 5. & Tina (INF5) & $\begin{array}{c}\text { Mrs. Tina's preferred POND'S products } \\
\text { because the brand was famous for its quality. } \\
\text { The low price was another reason why she } \\
\text { purchased them. }\end{array}$ & $\begin{array}{c}\text { Brand Choice } \\
\text { (Buyer's Response) } \\
\text { Price } \\
\text { (Marketing Stimuli) }\end{array}$ \\
\hline 6. & $\begin{array}{l}\text { Diah Widyastuti } \\
\text { (INF6) }\end{array}$ & $\begin{array}{l}\text { Positive brand image connected to POND'S } \\
\text { was the reason why Mbak Diah purchased and } \\
\text { used its products. } \\
\text { Another reason for her was the low price. }\end{array}$ & $\begin{array}{c}\text { Brand Choice } \\
\text { (Buyer's Response) } \\
\text { Price } \\
\text { (Marketing Stimuli) }\end{array}$ \\
\hline
\end{tabular}

Source: Primary Data Processed, 2018

\subsection{Comparison of Findings With Existing Studies}

This study aims to find out how consumers buy and use counterfeit POND'S products, explore the underlying causes of why consumers buy and use counterfeit POND'S products, and identify consumers' behavior regarding the distribution of counterfeit POND'S products. As a note, 
this study does not aim to produce generalized results outside the experience of this research's informants (samples). It is also important to compare their experiences in buying and using the counterfeit POND'S products with consumers' behavior when buying and using other types of counterfeit products. Positioning all research findings together with current research literature will increase the value of a qualitative study. Some of the main themes that emerged in this study are consistent with the previous research literature on consumers' behavior.

\subsection{How They Buy and Uses Counterfeit POND'S?}

Based on the results of interviews with the six informants, it is known that users of counterfeit POND'S products are women of productive age, which is between 34-45 years old. Some of them are factory workers, office girls, and administrative staff in a company in Malang with average monthly income ranging from Rp. 400.000 up to Rp. 1,000,000. All of them also have their own family. The levels of education of those informants vary, from primary school to high school. According to Morissan (2012) consumers can be grouped according to the level of education they have. The level of education usually determines their income and social status. Education also determines one's intellectual level. Although not always, someone's level of education is usually associated with their type of work. In this study, the informants have jobs (factory workers, administrative staff) that are in accordance with their level of education and intellect, hence affecting their choice of the beauty products they buy and use. Age also has a role in a consumer's decision-making process when buying products. Customers within the age of 35-50 are in their years of peak income (Kotler \& Armstrong, 2008). This explains why the informants tend to make their own decisions, even when buying and using counterfeit products. This is reinforced by the statement of Tommy (2012) which says that age greatly affects a consumer's decision in purchasing goods or services. Surely a child who has not worked will not make an excessive purchase. Likewise, someone who already has a job or better income is likely to make bigger purchase. Jobs also influence consumers' buying behavior. In this study, some informants have jobs that would not make it possible for them to buy expensive products, considering that their average incomes range between Rp. 400,000 and Rp. 1,000,000 per month. Someone who earns better income is certainly more likely to make a more expensive purchase. Low income also encourages consumers to buy and use counterfeit products. These consumers saw the purchase of counterfeit goods as being less risky. They generally had lower incomes and were less valueconscious than those who did not buy counterfeit goods. The fact that counterfeit cosmetics can cause health problems is not a concern for the consumers who prefer cheap counterfeit POND'S beauty products.

\subsubsection{Information Search of Counterfeit POND'S}

Information search by a consumer is the process when a consumer starts to look for information about a product or service. They may just need to pay more attention or actively search for information. This information enhances the consumer's knowledge and awareness of the available brand (Kotler \& Armstrong, 2008). From the results of the interviews with six informants, it is known that they start to get to know about counterfeit POND'S products from several sources, including:

a) Personal Sources (Fellows' Experience)

Essentially, the search of information involving colleagues is not much different from the reference group as a social factor that affects consumers' behavior in purchasing products. In the process of information search, there are two things that usually appear: information susceptibility and normative susceptibility (Bearden, Netemeyer, \& Teel, 1989; Wang, Zhang, Zang, \& Ouyang,

JEMA: Jurnal Ilmiah Bidang Akuntansi dan Manajemen is licensed under a Creative Commons Attribution 4.0 International License 
2005). Information vulnerability occurs when a purchase decision is taken based on an expert's opinion (Ang, Cheng, Lim, \& Tambyah, 2001; Wang, Zhang, Zang, \& Ouyang, 2005). Opinions from others must be very useful for a consumer who has very limited knowledge about a product. Friends who have previously used POND'S, either genuine or counterfeit, can provide an expert's opinion for the informants. For example, there were informants who knew about the existence of counterfeit POND'S from a friend who had been wearing POND'S cosmetics (either original or counterfeit) and testified that the results were satisfactory and without any side effects. This encouraged the informants to buy and use POND'S cosmetics. Meanwhile, another informant first knew about counterfeit POND'S products from one of their colleagues who was selling them and offered them personally. That informant was willing to try because she was interested and trusted their colleague's offer, without trying to find out about the pros and cons or the consequences of using the new products. Normative susceptibility itself concerns purchase decisions which are based on wishes to impress others (Ang, Cheng, Lim, \& Tambyah, 2001; Wang, Zhang, Zang, \& Ouyang, 2005; Penz \& Stöttinger, 2005). From the interviews with the informants, one informant did use POND'S moisturizer hoping to remove the wrinkles on her face and look better to others.

b) Commercial Sources (Ads)

As described on models of consumers' behavior toward marketing stimulus in the form of advertisement, the process of the purchase decision is strongly influenced by advertisements which are an important tool used by marketers to attract consumers. In the stage of information search, advertisements are used by informants to find information on a product, which in this case is of POND'S brand. Therefore, in creating ads, there are five basic factors, known as Five Ms, to consider (Kotler \& Keller, 2006). The Five M's of Advertising is as follows:

Mission: what are the advertising objectives?

Money: how much can be spent?

Message: what message can be sent?

Media: what media should be used?

Measurement: how should the results be evaluated?

The more information they obtain, the higher the awareness and knowledge that the consumers gain about the features of the available brands. This is proved by the results of a previous qualitative study conducted by Purnamawati (2009) entitled Female Road Sweepers Behavior toward Whitening Cosmetics in Medan City. The study showed that most of the female road sweepers in Medan thought beauty was strongly defined by light or fair skin tone. The physical and social environments, sources of information and references, and possible situations lead the female worker's behavior toward using skin whitening products. However, some of the women no longer use the whitening cosmetics for fear of having side effects, which allows for awareness campaign of cosmetic safety among women. This study showed that the source of information such as peer experiences and advertisements also encourage consumers to buy and use a product.

c) Alternative Evaluation (based on encouragement or intuition)

This is the stage whereby the consumers assess and rank option brand focused around the information they have (Kotler \& Armstrong, 2008). How consumers evaluate the alternatives depends on individual consumer and particular buying situation. In some cases, a consumer uses careful calculations and logical thinking. At other times, the same consumer does very little evaluation or even no evaluation at all. Instead, they make a purchase based on encouragement and intuition. This happens to INF 4 (informant 4) who decided to buy and use POND'S products based on her thoughts. INF 1 (informant 1) shares the same experience which she was trying new things, which in this case were counterfeit POND'S cosmetics, without considering the safety of the

JEMA: Jurnal Ilmiah Bidang Akuntansi dan Manajemen is licensed under a Creative Commons Attribution 4.0 International License 
products. This is reinforced by the theory of novelty search, which describes a consumer's curiosity to look for variants and other choices (Hawkins, Coney, \& Best, 1980; Wang, Zhang, Zang, \& Ouyang, 2005). Consumers with a tendency to try new products are likely to have a positive attitude toward counterfeit products.

\subsubsection{Where They Buy Counterfeit POND'S?}

The interviews with the informants provide information about where they usually buy POND'S products. This is related to store patronage (selection of where to get the product). Buying behavior is based on a consumer's choice and where they will carry out the purchase. For example, is the location of POND'S products seller one of the factors that influence the consumer's purchase decision? The informant's answers indicate that the location of the place where they buy the products is an important factor, it is near their workplace. This is very reasonable because it means they can save time and parking fees.

\subsection{Why They Buy and Uses Counterfeit POND'S?}

Consumers' purchase decisions are strongly influenced by cultural, social, personal, and psychological characteristics. Interviews with six informants in several themes related to factors that influence the consumers' behavior in purchasing counterfeit cosmetic products of POND'S in Malang. The dominant factors that affect their behavior in this study are the Social Factor (Reference Group) and Psychological Factor (Motivation and Belief). The discussion of each of these factors is as follows:

a) Social Factors (Reference Group)

Consumers' behavior is influenced by social factors. Several examples of these social factors are small groups, families, and the role and social status of consumers. A person's behavior is influenced by many small groups. The definition of a group is two or more people who are related to a common goal (Tommy, 2012). Social factors refer to the effect that a person has on other individual consumers (Ang, Cheng, Lim, \& Tambyah, 2001). In this study, the reference group, which was friends of the informants, had influenced the informants to follow their behavior in buying and using POND'S cosmetic. Such reference group motive is also described by the journals of Phau, Prendesgast, and Cheung (2001), and Field (2000) which show that the purchase of counterfeit products is supported by references from family, friends, and the fact that the product's quality is increasing. Thus, reference groups can encourage consumers to buy a product.

b) Psychological Factors

o Motivation

Furthermore, one's purchasing choices are influenced by five major psychological factors: motivation, perception, learning, and beliefs and attitudes. The interviews with the informants resulted in the theme of the psychological factor of motivation, where the reason behind the informants' decision to buy the products was to make their facial skin look better. This psychological need arises from the need for recognition, respect, or belonging. A need becomes a motive when it reaches a strong level of intensity. A motive is a need with high pressure that encourages a person to seek satisfaction of that need (Kotler \& Armstrong, 2008).

○ Belief

Belief and attitude affect consumers' buying behavior. Belief is a descriptive thought that someone has about something. It can be based on real knowledge, opinion, or faith, and can carry emotional content or not (Kotler \& Armstrong, 2008). The belief of the informants in this study on POND'S products makes them prefer to keep buying and using those products although they know that they are not legal and potentially harmful to the skin. Every individual has an attitude toward

JEMA: Jurnal Ilmiah Bidang Akuntansi dan Manajemen is licensed under a Creative Commons Attribution 4.0 International License 
religion, politics, clothes, music, food, and almost everything else. Attitude reflects a relatively consistent evaluation, feeling, and tendency of a person towards an object or idea. Attitude puts people into a frame of mind to like or dislike something, to move toward or move away from something. Attitude is a difficult thing to change. A person's attitude has a pattern, and to change one's attitude requires a complicated adjustment in many ways (Kotler \& Armstrong, 2008). This is evident in the attitude of INF 1 and INF 4 as they do not want to switch brands even though the cosmetics they used can harm the health and skin. This shows that belief and loyalty of consumers to a brand/product can make them ignore the negative sides of that product.

- Marketing Stimuli

Marketing stimuli consist of four P's: product, price, place, and promotion. Other stimuli include strengths and key factors in buyers' environment: economics, technology, politics, and culture. This study only found 3 marketing stimuli regarding models of consumers' behavior toward purchasing POND'S: promotion, product, and price. INF 6 claimed to be interested in POND'S cosmetics after seeing the ads on television. In this case, one marketing stimulus has succeeded in attracting INF 6 to make POND'S purchase. Meanwhile, a product is anything that can be offered to a market to satisfy people's needs or wants. Marketed products include something that can be seen or have a physical form, such as goods, people, places, property, organization, and something that can not be seen or do not have a physical forms such as services, experiences, activities, information, and ideas. A product can also refer to anything that can be offered to the market to be purchased, used or consumed, and can satisfy what the consumers want or need (Amir, 2005). Some informants in this study considered counterfeit POND'S products as concise and fit with their needs. They also believed that the usage met their expectations. That was why they bought it. Due to good packaging and display, consumers no longer pay attention to the safety of the products they use.

From a consumer perspective, the price is about what is given or sacrificed in an effort to obtain a product. He also distinguishes prices into objective prices (actual prices of a product) and perceived prices and concluded that his research has found that consumers do not always remember the actual price of a product, but they see the price in their opinion and to them, the price is only categorized as cheap or expensive. As stated by INF 4, if the price is below Rp50000, then it is cheap for her. That price can be a marketing stimulus is also supported by the journal of Bloch, Bush, \& Campbell (1993), which states that the reason why some people buy counterfeit products is that of low financial status (purchasing power).

○ Buyers' Response

INF 5's response to POND'S product purchase was based on her assumption that POND'S was a good brand. This is also reinforced by Tommy (2012) thesis about The Influence of Social and Personal Factors against Consumers' Attitudes and Intention to Buy Counterfeit Fashion Items in Denpasar City and Badung Regency. His research found that Social and Personal Factors have a positive and significant influence on consumers' attitude and intention. And ultimately, consumers' attitude has a positive and significant impact on their buying intention. Interviews with INF 1 and 4 also show that loyalty to the POND'S brand (both the originals and counterfeits) make the informants ignore the legality and security of the products they use. Customer loyalty is often aimed at a particular object, such as a brand, product, service, or store. In general, the brand is often used as the object of customers' loyalty. Brand loyalty reflects customers' loyalty to a particular brand. Several previous studies have shown that customers' satisfaction is the starting point for customer loyalty. This is confirmed in this study, in which informants become loyal to the POND'S brand after feeling satisfied with its products.

JEMA: Jurnal Ilmiah Bidang Akuntansi dan Manajemen is licensed under a Creative Commons Attribution 4.0 International License 


\subsection{Experiences in Using Counterfeit POND'S From Informant Perspective}

The results of interviews with six informants in this study showed that none of them have a bad experience with counterfeit POND'S products. This is possible because the side effects of counterfeit cosmetics usually emerge after long-term use. This is in accordance with the statement quoted by National Agency of Drug and Food Control (BPOM) and PT Unilever Indonesia Tbk that cosmetic products that contain harmful substances can damage the health of facial skin, although the time span needed for this to happen may vary with each user. The same finding is also presented in the journal of Widana (2007) which states that the harmful effect on skin health after the use of harmful dyes is skin irritation. Long-term exposure to a large amount of these substances can cause skin cancer. Other possibilities can also be due to the different resistance of each person's skin against harmful substances. It was possible that the 6 informants in this study have a high resistance against the harmful substances in counterfeit POND'S products (not medically proven).

\subsection{How They Respond After They Know An Information About Counterfeit POND'S?}

All informants in this study initially claimed to have never heard of government's appeal on television about the existence of BPOM's leaflets which prohibit the use of some cosmetic products containing harmful substances. This ignorance makes them buy and use counterfeit POND'S cosmetics without any feelings of doubt or fear at all. After the researcher informed them an indepth interview about the existence of illegal POND'S products that contain harmful substances, some of the informants decided to stop using the products immediately, reciting health concerns. They prefer to stop using the products or switch to legal cosmetics. However, some other informants insisted that they would still wear the counterfeit cosmetics regardless of the consequences of its use. These informants are categorized into the type of consumers who are willing to participate in buying counterfeit goods despite knowing that it is illegal activities. Cheap prices are often the reason why some consumers keep buying counterfeit products even though they are aware of the health risks (Tommy, 2012).

BPOM has issued a warning number: KH.00.01.43.2503 as of 11 JUNE 2009 concerning Cosmetics Containing Dangerous Material or Materials Prohibited, in which there is an appeal to the public to not buy/use cosmetics containing Harmful or Prohibited Substances due to health concerns. The interviews conducted in this study reveal that some informants still choose to use harmful cosmetics like counterfeit POND'S. Loyalty to the POND'S brand is the reason why some informants ignore the warnings and appeals from the the government (BPOM) and PT Unilever Indonesia Tbk as the official holder of POND'S brand. However, there is another important factor that contributes to consumers still buying and using counterfeit products: the lack of law enforcement and socialization of the dangers of using counterfeit cosmetic products. This is supported by the journal of Lai \& Zaichkowsky (1999) which mentions that experts are also aware of the strong influence of the environment toward counterfeit product purchase, such as inconsistent public policies, uncertainty of law enforcement, and the lack of transparent political and economic policy.

\subsection{Research Proportion}

$\mathrm{P}_{1} \quad$ Well recognized and reputable brand considered to be one of the reasons consumers choose to buy stimulation of brand POND'S.

$\mathrm{P}_{2} \quad$ Marketing stimuli such as advertising on television, the product that suits consumer needs in affordable price can stimulate consumers buying decision

$\mathrm{P}_{3} \quad$ Low price of POND'S counterfeit product is the main considerations in encouraging buying decision. 
$\mathrm{P}_{4} \quad$ High consumer loyalty toward original POND'S brand made them decide to buy counterfeit POND'S without considering the authenticity and its side effect on consumer health.

$\mathrm{P}_{5} \quad$ Reference group that dominate consumer minds in buying counterfeit POND'S product are workmate and store employees where the product is sold

$\mathrm{P}_{6}$ Motivation in seeking new products and the high level of trust toward Unilever brand (POND'S) encourages consumers to buy counterfeit POND'S

$\mathrm{P}_{7} \quad$ Private sources (office colleagues) and commercial (TV advertisement) considered as main information sources for consumer in buying POND'S and counterfeit POND'S counterfeit.

\section{RESEARCH CONCLUSION AND LIMITATION}

\subsection{Conclusion}

Consumers are attracted to POND'S products by the marketing stimuli, including promotion, products, and prices. Social factors (reference groups) and psychological factors (motivation and belief) are what encourage consumers to purchase counterfeit POND'S products. The notion that POND'S is a well-known and reputable brand makes them think that its counterfeit versions are as good as as the originals. Finally, the absence of complaints or consequences caused by the use of counterfeit POND'S as well as the lack of socialization of appeals and warnings from BPOM and related agencies fail to prevent some of the informants from using counterfeit POND'S products.

\subsection{Limitation}

This study certainly has some limitations. The purpose of this study is to explore the reasons why consumers buy and use fake POND'S products in Malang. All informants are female, as shown by willingness document. This is understandable because the majority of cosmetic users are women, although it does not rule out that there are also men who use cosmetics. Thus, the possible experience and reason of men in buying and using POND'S products that may be relatively different are not known. Informants' cautions in sharing their experiences of buying and using counterfeit products became another limitation to this research. They fear that engaging in the topic of this research will force them to face the law, and they feel that they know nothing about the laws and the appeal to not use counterfeit products. After a long period of conversation with the researcher, they began to open up and share more about their experience in buying and using fake POND'S products, but there was still possibility that they failed to provide complete transparency regarding their experience. Therefore, some important information may be lost or not disclosed. Further research is expected to be able to provide more insight into the behavior of consumers regarding the use of counterfeit products through the standpoints of income levels, education levels, and genders.

\section{REFERENCES}

Amir, T. (2005). Dinamika Pemasaran. Jakarta: Liberty

Ang, S. H., Cheng, P. S., Lim, E. A. C., \& Tambyah, S. K. (2001). Spot the Difference: Consumer Responses Towards Counterfeits. Journal of Consumer Marketing, 18(3), 219-35. https://doi.org/10.1108/07363760110392967.

Bearden, W. O., Netemeyer, R. G., \& Teel, J. E. (1989). Measurement of Consumer Susceptibility to Interpersonal Influence. Journal of Consumer Research, 15(4), 473-481 https://doi.org/10.1086/209186. 
Bloch, P. H., Bush, R. F., \& Campbell, L. (1993). Consumer Accomplices in Product Counterfeiting, A Demand Side Investigation. Journal of Consumer Marketing, 10(4), 27-36, . https://doi.org/10.1108/07363769310047374.

Bogdan, R. C., \& Biklen, S. K. (2003). Qualitative Research for Education: An Introduction to Theory and Methods, Fourth Edition. Needham Height, MA: Allyn \& Bacon.

Burkholder, D. U. (2009). Returning Counselor Education Doctoral Students: Issues of Retention and Perceived Experiences (Doctoral dissertation. Kent State University College and Graduate School of Education, Health, and Human Services).

Creswell, J. W. (2007). Qualitative Inquiry and Research Design: Choosing among Five Traditions, Second Edition. Thousand Oaks, CA: Sage Publications.

Field, J. R. B. (2000). An Empirical Investigation of Consumers' Perceptions and Purchase Intentions of Counterfeit Products: A Means-End Chain Analysis (Doctoral dissertation. Mississippi State University).

Hawkins, D. I., Coney, K. A., \& Best, R. J. (1980). Consumer Behavior: Implications for Marketing Strategy. Dalass, Texas: Business Publications.

Hidayat, A. \& Mizerski, K. (2005). Pembajakan Produk: Problema, Strategi dan Antisipasi Strategi. Jurnal Siasat Bisnis, 1(10), 95-122.

Peter, J. P., \& Olson, J. C. (2005). Consumer Behaviour, Perilaku Konsumen dan Strategi Pemasaran. Jakarta: Penerbit Erlangga.

Kotler, P., \& Armstrong, G. (2008). Principles of Marketing. Twelfth Edition. New Jersey : Pearson Education, Inc.

Kotler, P., \& Keller, K. L. (2006). Marketing Management. Twelfth Edition. New Jersey : Pearson Education, Inc.

Lai, K. K. Y. \& Zaichkowsky, J. L. (1999). Brand Imitation: Do the Chinese have different views? Asia Pacific Journal of Management, 16, 179-192. https://doi.org/10.1023/A:1015482707900.

Maxwell, J. A. (2005). Qualitative Research Design: An Interactive Approach, Second Edition. Thousand Oaks. CA: Sage Publications.

Morissan. (2012). Sales Marketing. Pokok Bahasan: Segmentasi Pasar. Modul 6. Universitas Mercubuana.

Nieswiadomy, R. M. (2002). Foundation of Nursing Research. Fourth Edition. Upper Saddle River: Prentice Hall.

Penz, E., \& Stöttinger, B. (2005). Forget the Real Thing-Take the Copy! An Explanatory Model for the Volitional Purchase of Counterfeit Products. Advances in Consumer Research, 32, 56875. .

Poerwandari, E. K. (2001). Pendekatan Kualitatif untuk Penelitian Perilaku Manusia, Edisi Revisi Jakarta: LPSP3 UI.

Purnamawati, S. S. (2009). Perilaku Pekerja Perempuan Penyapu Jalan Terhadap Kosmetik Pemutih di Kota Medan (Doctoral dissertation, Thesis. Program Studi Magister Ilmu Kesehatan Masyarakat Fakultas Kesehatan Masyarakat Universitas Sumatra Utara, Medan). 
Sugiyono. (2011). Metode Penelitian Kuantitatif, Kualitatif, dan $R \&$ D. Bandung: Alfabeta.

Tommy, H. T. (2012). Pengaruh Faktor Sosial Dan Personal Terhadap Sikap Dan Niat Beli Konsumen Untuk Barang Fashion Palsu di Kota Denpasar Dan Kabupaten Badung (Doctoral dissertation, Thesis, Program Pascasarjana Universitas Udayana, Denpasar).

Wang, F., Zhang, H., Zang, H., \& Ouyang, M. (2005). Purchasing Pirated Software: an Initial Exaniation of Chinese Consumers. Journal of Consumer Marketing, 22(6), 340-51. https://doi.org/10.1108/07363760510623939.

Widana, G. A. B, \& Yuningrat, N. W. (2007). Analisis Bahan Pewarna Berbahaya Pada Sediaan Kosmetika Di Wilayah Kecamatan Buleleng Kabupaten Buleleng. Jurusan Analis Kimia, Fakultas MIPA Undiksha. Jurnal Penelitian dan Pengembangan Sains \& Humaniora, 1(1), 26-36.

*) Risca Kurnia Sari, Department of Agribusiness, Agriculture Institute, Malang, Indonesia (Email : risca.kc@gmail.com)

**) Achmad Soediro, Department of Accounting, Sriwijaya University, Palembang, Indonesia (Email : achmadsudiro@yahoo.com)

***) Fatchur Rochman, Department of Management, Brawijaya University, Malang, Indonesia (Email : fatchur@ub.ac.id) 